\title{
Improving Post Abortion Care (PAC) Delivery in Sub-Saharan Africa: A Literature Review
}

\author{
Alphonse Nyong Ngalame ${ }^{1 *}$, Robert Tchounzou ${ }^{1,2}$, Humphry Tatah Neng1, \\ Fulbert George Nkwele Mangala ${ }^{3}$, Rakya Inna ${ }^{1,4}$, Diane Modjo Kamdem, \\ Bilkissou Moustapha' ${ }^{1}$, Julius Sama Dohbit ${ }^{5}$, Eugene Justine Kongnyuy ${ }^{6}$, \\ Claude Ndoua Noa ${ }^{5}$, Benova Lenka7 ${ }^{7}$ Gregory Ekane Halle², Darolles Wekam Mwadjie1, \\ Therese Delvaux ${ }^{7}$, Emile Telesphore Mboudou1,3,5
}

${ }^{1}$ Gynecology \& Obstetrics Unit, Douala Gyneco-Obstetric and Pediatric Hospital (DGOPH), Douala, Cameroon

${ }^{2}$ Faculty of Health Sciences (FHS), University of Buea, Buea, Cameroon

${ }^{3}$ Faculty of Medicine and Pharmaceutical Sciences, University of Douala, Douala, Cameroon

${ }^{4}$ Faculty of Medicine and Biomedical Sciences (FMBS), University of Ngaoundere, Ngaoundere, Cameroon

${ }^{5}$ Faculty of Medicine and Biomedical Sciences (FMBS), University of Yaounde I, Yaounde, Cameroon

${ }^{6}$ United Nations Population Fund (UNFPA), Bamako, Mali

${ }^{7}$ Institute of Tropical Medicine (ITM), Antwerpen, Belgium

Email: *anngalame2000@gmail.com

How to cite this paper: Ngalame, A.N., Tchounzou, R., Neng, H.T., Mangala, F.G.N., Inna, R., Kamdem, D.M., Moustapha, B., Dohbit, J.S., Kongnyuy, E.J., Noa, C.N., Lenka, B., Halle, G.E., Mwadjie, D.W., Delvaux, T. and Mboudou, E.T. (2020) Improving Post Abortion Care (PAC) Delivery in Sub-Saharan Africa: A Literature Review. Open Journal of Obstetrics and Gynecology, 10, 1295-1306. https://doi.org/10.4236/ojog.2020.1090119

Received: August 17, 2020

Accepted: September 20, 2020

Published: September 23, 2020

Copyright $\odot 2020$ by author(s) and Scientific Research Publishing Inc. This work is licensed under the Creative Commons Attribution International License (CC BY 4.0).

http://creativecommons.org/licenses/by/4.0/ (c) (i) Open Access

\begin{abstract}
Sub-Saharan Africa (SSA) contributes $29 \%$ of the global unsafe abortions with $62 \%$ of abortion-related deaths. This is due to restrictive abortion laws, low quality post abortion care (PAC) and inadequate access to effective modern contraception. The overall objective was to review current literature on PAC in SSA and make recommendations for improvement especially in Cameroon. A literature review was conducted on PAC in SSA published during 2000-2018. The following databases were searched: MEDLINE, POPLINE, COCHRANE Library, African Index Medicus and GOOGLE Scholar. Thirty articles were reviewed from 16 countries ranging from observational studies to systematic reviews with meta-analysis. Major outcomes: 1) Manual vacuum aspiration (MVA) and misoprostol are equally safe and effective. 2) There is comparable effectiveness between physicians and trained mid-level cadres in PAC management. 3) PAC contraception uptake was increased when offered immediately before patient leaves the facility. 4) Gaps to PAC service use include inadequate access, low quality care and less adolescent-friendly environment. Task shifting of PAC to trained mid-level staff, decentralization of medical PAC using misoprostol, offering post abortion counselling and contraception to clients before leaving the health facility, encouraging linkage and provider-community partnership in PAC and reinforcement of advocacy for less restrictive abortion laws in Cameroon are recommended.
\end{abstract}




\section{Keywords}

Post Abortion Care (PAC), Misoprostol, Contraception, Midlevel Cadres, Sub-Saharan Africa

\section{Introduction}

Abortion is the termination of pregnancy before the age of viability of the fetus. Abortion can be classified as either spontaneous or induced, early or late and safe or unsafe [1] [2]. World Health Organization (WHO) defines unsafe abortion as a procedure for termination of a pregnancy done either by an individual lacking the necessary training or in an environment not conforming to minimal medical standards or both [3].

Abortion is a major public health problem especially in developing countries, resulting in severe complications including maternal death [3]. Globally, it is estimated that one in every five pregnancies ends up in an abortion [4]. According to WHO, about 56 million abortions occur worldwide each year, with over 25 million (45\%) of them being unsafe [4] [5]. In a 2017 United Nations database report, countries with more restrictive abortion laws had about four times higher unsafe abortion rates and maternal mortality ratios (MMR) [6]. Over 13\% of maternal deaths in the world are attributed to unsafe abortions and its complications such as bleeding, pelvic infection or abscess, genital trauma, secondary infertility and death [7] [8]. Worldwide, an estimated 7 million complications result from unsafe abortions [5]. This alarming figure is maintained by the very high proportion of unintended pregnancies in these developing countries.

Sub-Saharan Africa (SSA) is the most hit region as far as unsafe abortion related maternal morbidity and mortality are concerned [3]. While it is estimated that 30 women die for every 100,000 unsafe abortions in developed countries, over 520 women die for every 100,000 unsafe abortions carried out in SSA [3] [7]. Likewise, while the African region sees $29 \%$ of all unsafe abortions, it contributes $62 \%$ of the total unsafe abortion-related maternal deaths [3] [5]. WHO estimates that $30 \%-40 \%$ of maternal deaths in SSA are due to induced unsafe abortion [3] [9]. This is partly due to the restrictive abortion laws in most countries of SSA and equally the low modern contraceptive use [10]. Of the 214 million women having unmet needs for family planning, $24.2 \%$ are from Africa [5]

The Sustainable Development Goals (SDG) 3.1 states that "the global maternal mortality ratio should be reduced to less than 70 per 100,000 live births" [10] [11]. Post abortion care (PAC) through manual vacuum aspiration (MVA) of retained products of conception is one of the seven signal functions of basic emergency obstetric and newborn care (BEmONC) and this constitutes one of the global strategies for the fight against unsafe abortion-related maternal mortality [12].

Post abortion care (PAC) directed at women with incomplete abortion is a package of five activities as shown in Figure 1, which include: 1) the emergency 
management of complications related to abortions; 2) offer counselling on the patients' needs and family planning; 3 ) the provision of modern contraception; 4) linkage to other reproductive health care services such as screening for sexually transmissible infections and gynecological cancers; and 5) to facilitate her social reinsertion and prevent future unsafe abortion cases via provider-community partnership [13].

The maternal mortality rates (MMR) of Cameroon, which stands at 782 maternal deaths per 100.000 live births is one of the highest in SSA and has been rising over the past two decades [14] [15]. One of the main reasons is explained by the low modern contraceptive prevalence rate (CPR) of $19.3 \%$, the high unintended pregnancy rate of $40 \%$, high unsafe abortions and the insufficient care for these women [15] [16]. Abortions account for about 30\% of total maternal deaths in the country [9] [17] [18]. In a country like Cameroon, where all previous measures implemented over the decades have not succeeded in reversing the MMR, ignoring a determinant factor such as contraception, can only render the fight impossible to win.

Cameroon is a country where abortion laws are restrictive, allowed only in cases of rape and to save mothers life [19]. This has led to an increase in unsafe abortions and thus maternal morbidity and mortality [5] [20]. The main strategy to fight maternal deaths is to offer comprehensive abortion care where possible. It entails providing safe abortion, where country laws permit and quality post abortion care (PAC). The WHO recommends that quality PAC be offered in all the health facilities (HF) in the country and by all trained health cadres [1].

In order to understand how PAC is practiced in Cameroon, and how these services can be improved so as to help curb the rising abortion-related maternal deaths, we conducted this literature review of successful approaches of PAC in other sub-Saharan African countries with similar contexts. Our goal was to draw lessons from these countries and make evidence-informed recommendations in order to improve the uptake and quality of PAC services offered in Cameroon.

\section{Methods}

\section{Search methods}

On the $24^{\text {th }}$ May 2018, we searched for published articles on post abortion care

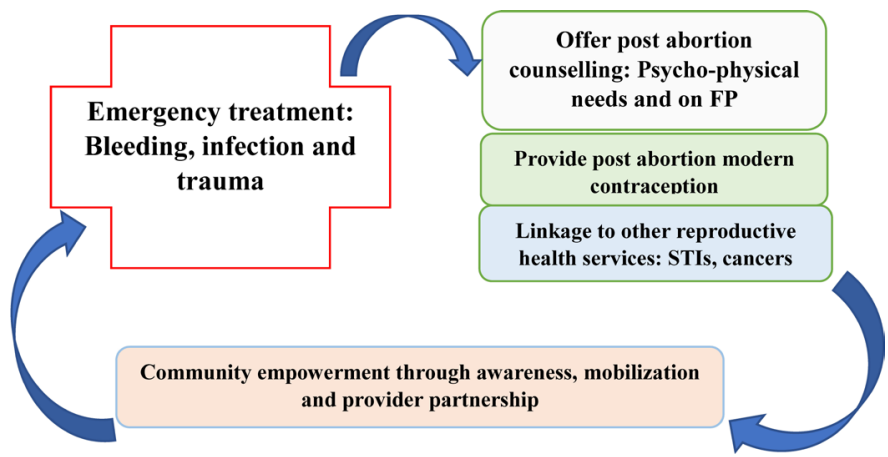

Figure 1. The five core components of the post abortion care (PAC) model. 
services offered in SSA in the following databases; Cochrane (CENTRAL), POPLINE, African Index Medicus (AIM), GOOGLE SCHOLAR and MEDLINE using diverse and relevant Medical sub headings (MeSH) and search terms concerning our topic of interest, such as; "Post abortion care" AND "Sub Saharan Africa", "Abortion care" AND "Africa".

\section{Selection criteria}

All articles which met with the following criteria: 1) Published in English language only, 2) Published between the years 2000 and 2018, 3) Both experimental and non-experimental studies, 4) All articles addressing at least a component of post abortion care either in a specific country, or in a sub-region or in the entire SSA region; were included in the study.

\section{Data collection and analysis}

For each selected article, we screened the abstracts for eligibility, noted the study design and extracted the results and lessons learned from the study.

\section{Ethical considerations}

Ethical clearance was obtained from the Institutional Review Board (IRB) of the Institute of Tropical Medicine (ITM), Antwerp in Belgium.

\section{Results}

Information from each selected article was entered into a summary table of four sections: study selected, study design, country and outcomes. After excluding irrelevant articles and duplicates, we found a total of 30 articles which met with the inclusion criteria, as shown in Figure 2. The number of articles retrieved from each of the databases was as follows: MEDLINE (11), POPLINE (09), GOOGLE SCHOLAR (06), COCHRANE CENTRAL (02) and African Index Medicus (02). These studies were conducted in a total of 16 SSA countries representing all the four sub-regions as follows: 3 from Cameroon (Central Africa), 4 from Southern Africa, 10 from East Africa and 13 from West Africa as shown in Table 1.

According to their strengths of evidences, we retrieved a systematic review with meta-analysis on septic abortion. There were three systematic reviews, on the timing of PAC-IUD insertion, the safety and effectiveness of abortion care by midlevel cadres and doctors, and PAC in 14 countries in east and southern Africa. We equally found one literature review on the role of midlevel staff in PAC. There were two randomized controlled trials (RCTs); one in Burkina Faso on the safety and effectiveness of misoprostol versus MVA in PAC, while the other verified differences between PAC misoprostol use by midwives and doctors in Kenya. We had 6 quasi-experimental (before and after intervention) impact evaluations. The majority (56.7\%) were however observational studies on the burden of unsafe abortion and practices of PAC. Detailed results are displayed in Table 1.

The main lessons learned from this review included: 1) Factors limiting the utilization of PAC services include; inadequate knowledge, high cost, less 


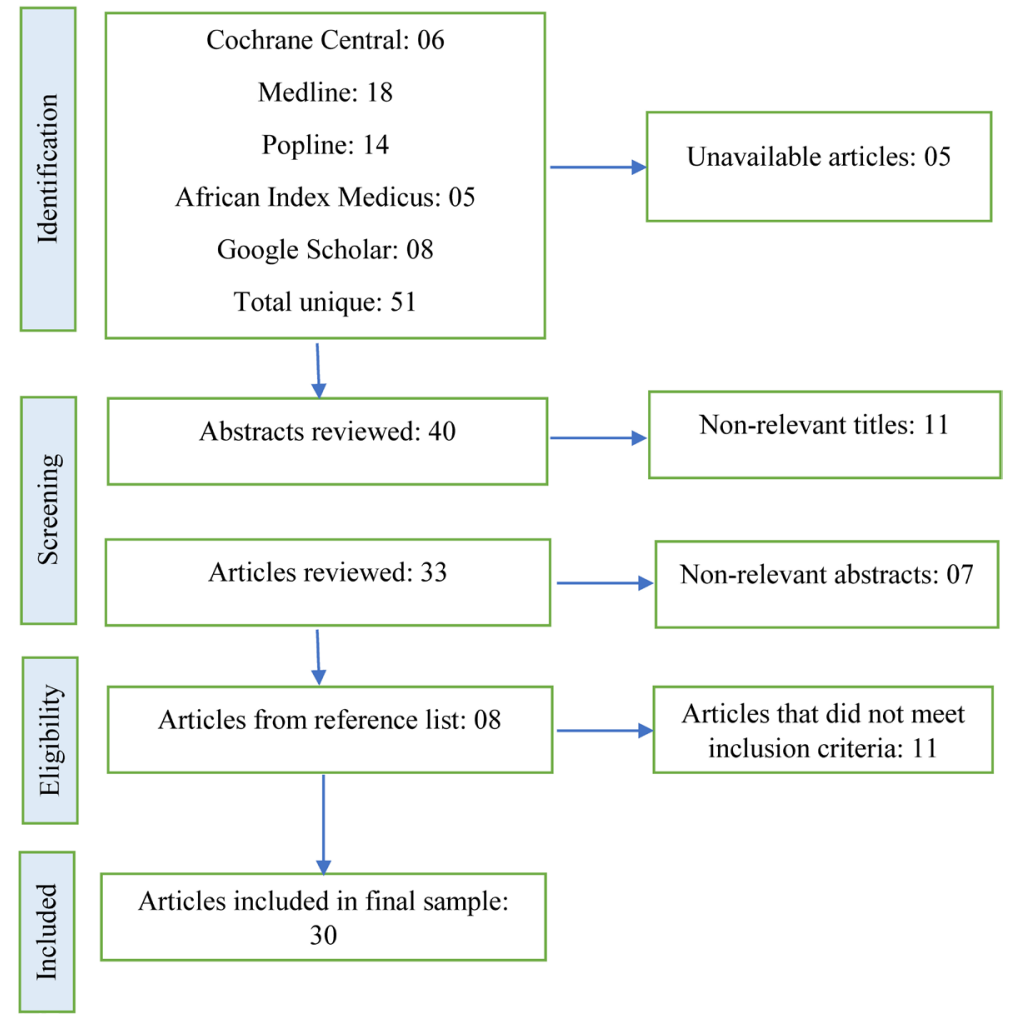

Figure 2. Results of search.

Table 1. Major results of the review of literature on PAC in SSA from 2000-2018. Arranged in order of decreasing strength of evidence and then chronologically.

\begin{tabular}{|c|c|c|c|}
\hline First Author & Country of study & Study type and aim & Study outcomes \\
\hline Udoh, 2016. & Nigeria & $\begin{array}{c}\text { Systematic review }+ \text { Metanalysis: Septic } \\
\text { abortion }\end{array}$ & $\begin{array}{l}\text { No evidence that one antibiotic was better than } \\
\text { another in treatment. }\end{array}$ \\
\hline Aanties, 2018. & 14 countries from Africa. & Systematic review of PAC & $\begin{array}{l}\text { Gaps of PAC services: Quality, access to rural } \\
\text { women, knowledge, teenagers. }\end{array}$ \\
\hline Barnard, 2015. & South Africa +3 others & $\begin{array}{c}\text { Systematic review: PAC and level of } \\
\text { HCP }\end{array}$ & $\begin{array}{l}\text { Safety and effectiveness in PAC methods were the } \\
\text { same for MWs and MDs. }\end{array}$ \\
\hline Okusanya, 2014. & Nigeria & Systematic review: RCT on PAC-IUD & $\begin{array}{l}\text { Moderate evidence supports the safety of immediate } \\
\text { PAC-IUD insertion. }\end{array}$ \\
\hline Berer, 2009. & $\begin{array}{l}\text { Mozambique, Uganda, Kenya, } \\
\text { South Africa. }\end{array}$ & $\begin{array}{l}\text { Literature review: role of trained } \\
\text { mid-level staff in PAC }\end{array}$ & $\begin{array}{l}\text { Authorize qualified trained mid-level staff to offer } \\
\text { first trimester abortion/PAC using misoprostol and } \\
\text { MVA. }\end{array}$ \\
\hline Makenzius, 2017. & Kenya & $\begin{array}{c}\text { RCT: MWs and MD on misoprostol } \\
\text { use. }\end{array}$ & $\begin{array}{l}\text { Equal treatment outcomes (effectiveness and safety) } \\
\text { in } 2 \text { groups. }\end{array}$ \\
\hline Dao, 2007. & Burkina Faso & RCT: misoprostol versus MVA in PAC. & $\begin{array}{l}\text { Equal safety and effectiveness of misoprostol and } \\
\text { MVA PAC. }\end{array}$ \\
\hline Benson, 2018. & $\begin{array}{c}3 \text { Asian and } 5 \text { African } \\
\text { countries (Zambia, Nigeria, } \\
\text { South Africa, Ghana, Ethiopia) }\end{array}$ & $\begin{array}{l}\text { Program evaluation by IPAS on quality } \\
\text { training in FP }\end{array}$ & $\begin{array}{l}\text { Uptake of modern FP (73\%). Highest when } \\
\text { delivered at the time of PAC. }\end{array}$ \\
\hline Benson, 2017. & $\begin{array}{l}5 \text { Asian and } 5 \text { African } \\
\text { countries (Zambia, Nigeria, } \\
\text { Sierra Leone, Ghana, Uganda) }\end{array}$ & $\begin{array}{l}\text { Program evaluation IPAS quality } \\
\text { training and lifting cost to FP }\end{array}$ & $\begin{array}{c}\text { Uptake of modern FP (77\%). Choices: OCP, } \\
\text { condom, injectable. Adolescents less likely to leave } \\
\text { HF with an FP method. }\end{array}$ \\
\hline
\end{tabular}




\section{Continued}

\begin{tabular}{|c|c|c|c|}
\hline $\begin{array}{l}\text { Chukwumalu, } \\
2017 .\end{array}$ & Puntland-Somalia & $\begin{array}{c}\text { Impact Evaluation: SCI created } 4 \text { PAC } \\
\text { facilities }\end{array}$ & $\begin{array}{l}\text { Increased utilization of services. counselling (98\%), } \\
\text { accepted FP (88\%). }\end{array}$ \\
\hline Mugore, 2016. & Togo & $\begin{array}{c}\text { Program evaluation: Quality HCPs } \\
\text { training }\end{array}$ & $\begin{array}{c}\text { Increased PAC counselling from } 31 \% \text { to } 91 \% \text { and FP } \\
\text { uptake from } 37 \% \text { to } 60 \% \text {. }\end{array}$ \\
\hline Maxwell, 2015. & Ghana & $\begin{array}{c}\text { Retrospective cohort: Provider and FP } \\
\text { uptake }\end{array}$ & $\begin{array}{l}\text { Women receive an FP method more if PAC is done } \\
\text { by MWs compared to MDs. }\end{array}$ \\
\hline Tumasang, 2014. & Cameroon & $\begin{array}{l}\text { Ambidirectional: MVA distribution } \\
\text { evaluation }\end{array}$ & $\begin{array}{l}\text { MVA and misoprostol are seldom available in HF } \\
\text { even in the cities. }\end{array}$ \\
\hline Solo, 2003. & Kenya & $\begin{array}{l}\text { Cross sectional pre and post } \\
\text { intervention FP }\end{array}$ & $\begin{array}{l}\text { Most effective strategy: Offer PAC-FP in the } \\
\text { gynecological ward by ward staff. }\end{array}$ \\
\hline Hagos, 2018. & Ethiopia & $\begin{array}{l}\text { Cross sectional: Uptake of PAC-FP } \\
\text { predictors }\end{array}$ & $\begin{array}{l}\text { FP uptake: } 70.9 \% \text {. Associations: Husbands } \\
\text { opposition, delays in and type of HF, knowledge of } \\
\text { pregnancy risk. }\end{array}$ \\
\hline Kemfang, 2015. & Cameroon & Cross sectional: Abortion burden & $\begin{array}{l}\text { Induced abortion } 26.3 \% \text {, complications ( } 20 \%) \text {, } \\
\text { severe bleeding }(70 \%) \text {. }\end{array}$ \\
\hline Rominskia, 2015. & Ghana & Cross sectional study of PAC & $\begin{array}{c}\text { LARCs are better for adolescents and single women } \\
\text { to prevent recurrences. }\end{array}$ \\
\hline Nkwabong, 2014. & Cameroon & $\begin{array}{l}\text { Cross sectional on clandestine } \\
\text { abortions }\end{array}$ & $\begin{array}{c}\text { Incomplete abortion (16\%), anemia (25\%), infection } \\
(18 \%) \text {, death (2.1\%). }\end{array}$ \\
\hline Evens, 2014. & Kenya & Cross sectional descriptive study & $\begin{array}{l}49 \% \text { youths not using FP due to fear of side effects } \\
\text { and lack of knowledge. }\end{array}$ \\
\hline Esber, 2014. & Tanzania & Cross sectional. Partner approval FP & $\begin{array}{l}\text { Strong association between partner approval and } \\
\text { contraception use in PAC. }\end{array}$ \\
\hline Paul, 2014. & Uganda & Qualitative: HCPs on PAC task-sharing & $\begin{array}{l}\text { Scale-up task sharing and in-service training of } \\
\text { cadres (PAC + misoprostol). }\end{array}$ \\
\hline Gerdts, 2012. & Ethiopia & $\begin{array}{l}\text { Cross sectional. Abortion } \\
\text { complications }\end{array}$ & $\begin{array}{l}\text { Severe complications associated with being married } \\
\text { and care from low HF. }\end{array}$ \\
\hline Kalu, 2012. & Nigeria & Cross sectional: hospital PAC review & $\begin{array}{c}41 \% \text { admissions, } 11.5 \% \text { deaths, } 7.1 \% \text { teenagers, } 25 \% \\
\text { single, poor linkage. }\end{array}$ \\
\hline Basinga, 2012. & Rwanda & National survey on PAC & Induced abortion rate: $25 / 1000$. \\
\hline Prata, 2011. & Ethiopia & Cross sectional: PAC-FP predictors & $\begin{array}{l}\text { LARCs uptake associated to secondary education, } 25 \\
\qquad-29 \text { years and multiparity. }\end{array}$ \\
\hline Adinma, 2010. & Nigeria & Cross sectional: HCPs PAC practices & $\begin{array}{l}35.5 \% \text { used an MVA for PAC. } \\
88 \% \text { offered PAC counselling. }\end{array}$ \\
\hline Rabiu, 2009. & Nigeria & $\begin{array}{l}\text { Cross sectional: Unsafe abortion } \\
\text { complications }\end{array}$ & $\begin{array}{l}\text { Complications: incomplete abortion, anemia, } \\
\text { infection, case fatality rate: } 9 \% .\end{array}$ \\
\hline Thiam, 2006. & Senegal & $\begin{array}{l}\text { Impact evaluation (provider training, } \\
\text { free MVA kits in } 23 \text { districts, } 50 \% \text { total } \\
\text { population from 2003-2005) }\end{array}$ & $\begin{array}{l}\text { Availability of trained HCPs of PAC in health } \\
\text { centers: From } 39 \% \text { to } 100 \% \text {. Women seeking PAC } \\
\text { services doubled. PAC counselling: } 36 \% \text { to } 82 \% \text {. } \\
\text { Uptake of contraception: } 15 \% \text { to } 56 \% \text {. }\end{array}$ \\
\hline Krakowiak, 2011. & Ghana & Community FP awareness survey & $\begin{array}{l}\text { 1/3 fear side effects of FP methods. Train HCPs on } \\
\text { FP counselling. }\end{array}$ \\
\hline Singh, 2006. & $\begin{array}{l}\text { Nigeria, Uganda, Kenya, } \\
\text { Burkina, Egypt, South Africa, } \\
\text { Ghana+ }\end{array}$ & $\begin{array}{l}\text { National estimates of abortion-related } \\
\text { hospital admissions }\end{array}$ & $\begin{array}{l}\text { Highest rates in certain African countries: } 15 \% \text { per } \\
\text { year. The introduction of misoprostol in safe } \\
\text { abortion/PAC will help reduce this rate. }\end{array}$ \\
\hline
\end{tabular}

Abbreviations: MWs: Midwives, HCPs: Health Care Providers, MDs: Medical Doctors, IUD: Intrauterine device, RCT: Randomized Controlled Trial, MVA: Manual Vacuum Aspiration, HF: Health Facility, OCP: Oral Contraceptive Pill, LARCs: Long Acting Reversible Contraceptives. 
adolescent-friendly services and fear of side effects of modern FP [21]. 2) Abortion still represents a high burden in most countries of SSA [18] [22] [23]. 3) Hemorrhage, sepsis and maternal death are the major post abortion complications [8] [18] [24]. 4) Misoprostol and MVA have comparable efficiency and safety in PAC, especially in the first trimester [25]. 5) Trained mid-level health cadres and physicians produce comparable results in the use of misoprostol and MVA in uncomplicated abortion care [26] [27]. 6) There is increase uptake of modern contraception if PAC counselling and FP are available and offered immediately in the same room where emergency PAC was carried out before patient leaves the ward [28] [29]. 7) The training of HCPs on quality PAC, husband authorization and constant availability of FP method mix improves significantly the uptake of modern contraception, especially LARCs [28] [30] [31] [32].

\section{Discussion}

Worldwide, countries are classified into six categories according to the degree of restriction of their abortion laws [10]. Articles reviewed represented all these categories as follows: Category 1, where abortion is prohibited was represented by Senegal [33]. Category 2, where abortion is legal only to save the woman's life was represented by Nigeria, Somalia, Tanzania and Uganda [21] [22] [30] [31] [34] [35]. Category 3, where abortion is legal only to save the woman's life and preserve her physical health was represented by Burkina Faso, Cameroon (including case of rape), Ethiopia, Kenya, Rwanda and Togo [8] [25] [26] [36] [37] [38]. Category 4, where abortion is authorized to save the woman's life and preserve her physical and mental health was represented by Ghana, Mozambique and Sierra Leone [21] [28] [30] [39]. Category 5, where abortion is authorized to save the woman's life, preserves her physical and mental health and on economic grounds was represented by Zambia [21] [30]. Finally, category 6 where there are no restrictions to safe abortion upon request represented by South Africa [21] [28] [40].

Countries with restrictive abortion laws, such as Cameroon and Nigeria have highest unsafe abortion burden [41]. Hospital studies in Nigeria reported a specific mortality rate due to abortions of $11.5 \%$, with case fatality rates as high as 9\% [22] [42]. Similar in Cameroon, unsafe abortions contributed to $24.2 \%$ of MMR as well as a high case fatality rate of $2.1 \%$ [9] [18].

Training of HCPs is known to improve the uptake of PAC services. According to an IPAS evaluation study in five SSA countries showed that the factors associated with increased uptake of PAC contraception were; young maternal age, availability of commodities, training of HCPs and cost [21] [28] [41] [43]. From our study, we found that the main complications of unsafe abortion were similar in SSA countries. These include; incomplete abortion, severe bleeding and infection [8] [18] [22] [23] [24]. Similarly, PAC-FP uptake was boosted by the availability of a separate evacuation room and immediate provision of method mix contraception prior to discharged from the HF [21] [29] [44] [45]. This is a rare 
practice in Cameroon, where often the two services are separate.

To fight against these complications of unsafe abortion, task shifting is crucial in low resource settings as SSA. Well trained mid-level health cadres in SSA were found to have comparable acceptability, safety and effectiveness to physicians in the management of incomplete first trimester abortions [26] [27] [40]. They were found to use equally either misoprostol or MVA in treatment and this is in line with the WHO recommendations [46]. This task shifting will relieve physicians, reduce delay to HF and PAC and thus reduce complications and cost [47]. However, in Cameroon, midlevel cadres are hardly authorized to manage emergency PAC.

The use of Misoprostol or MVA in the management of first trimester incomplete abortion and in medical abortion, had similar safety and effectiveness outcomes [25] [26] [48]. As seen above, these two methods can be handled easily by all trained health personnel. Availing these two commodities is thus of utmost importance in all HF and to all trained HCPs in order to meet the needs of patients irrespective of their means and geographical location in the country [33] [49] [50] [51] [52]. In Cameroon, misoprostol is seldom available to practitioners at all levels of care.

The strengths of our study reside in a detailed review of literature on PAC from five databases. The study designs varied from observational through randomized controlled trials to systematic reviews, representing 18 countries from all the four sub-regions of SSA. Mindful of the similarity in context of SSA, successful PAC service models from other SSA countries could be generalized in Cameroon. However, the main limitation is selection bias, since we retained mostly articles from countries with successful approaches of PAC services. Equally, we did not include studies published in other languages such as French, since we had enough articles in English. Finally, we did not explore in detail, the community component of PAC in this study.

\section{Conclusion}

In conclusion, abortion remains a major health problem in Cameroon and in SSA countries where safe abortion is authorized only under restrictive conditions leading to severe maternal complications. Though the practice of quality accessible PAC has been well codified by WHO and FIGO, these norms are diversely and seldom applied in SSA countries especially Cameroon. Though efforts have been made to improve the quality and access to PAC in Cameroon, much still has to be done. Conscious of the fact that the legalization of abortion might need a long time to change, advocacy towards less restrictive abortion laws in the country must be intensified. We recommend to the Society of Gynecologists and Obstetricians of Cameroon (SOGOC) and the Ministry of Health to improve access to quality PAC by task shifting to trained mid-level cadres and ensure regular supply of PAC commodities in the country. 


\section{Acknowledgements}

We are immensely grateful to the Institute of Tropical Medicine (ITM) Antwerpen, Belgium for their training and technical support. We equally wish to thank the Belgian Development Cooperation (DGD) for offering us the financial assistance and enabling environment that permitted us to realize this work.

\section{Conflicts of Interest}

The authors declare no conflicts of interest regarding the publication of this paper.

\section{References}

[1] World Health Organization (2014) Clinical Practice Handbook for Safe Abortion. WHO, Geneva, 72 p.

[2] Grimes, D.A., Benson, J., Singh, S., Romero, M., Ganatra, B., Okonofua, F.E. and Shah, I.H. (2006) Unsafe Abortion: The Preventable Pandemic. The Lancet, 368, 1908-1919. https://doi.org/10.1016/S0140-6736(06)69481-6

[3] Ganatra, B., Gerdts, C., Rossier, C., Johnson Jr., B.R., Tunçalp, O., Assifi, A., Sedgh, G., Singh, S., Bankole, A., Popinchalk, A., Bearak, J., Kang, Z. and Alkema, L. (2017) Global, Regional, and Sub Regional Classification of Abortions by Safety, 2010-14: Estimates from a Bayesian Hierarchical Model. The Lancet, 390, 2372-2381. https://doi.org/10.1016/S0140-6736(17)31794-4

[4] Sedgh, G., Bearak, J., Singh, S., Bankole, A., Popinchalk, A., Ganatra, B., Rossier, C., Gerdts, C., Tunçalp, O., Johnson Jr., B.R., Johnston, H.B. and Alkema, L. (2016) Abortion Incidence Between 1990 and 2014: Global, Regional, and Sub Regional Levels and Trends. The Lancet, 388, 258-267. https://doi.org/10.1016/S0140-6736(16)30380-4

[5] World Health Organization (2018) Geneva: Preventing Unsafe Abortion, Fact Sheet. http://www.srhr.org/abortion-policies

[6] Johnson, B.R., Mishra, V., Lavelanet, A.F., Khosla, R. and Ganatra, B. (2017) A Global Database of Abortion Laws, Policies, Health Standards and Guidelines. Bulletin of the World Health Organization, 95, 542-544. https://doi.org/10.2471/BLT.17.197442

[7] World Health Organization. (2012) Safe Abortion: Technical and Policy Guidance for Health Systems. WHO, Geneva, $134 \mathrm{p}$.

[8] Kemfang Ngowa, J.D., Neng, H.T., Fokom, J.D., Nsahlai, C.J. and Kasia, J.M. (2015) Voluntary Induced Abortion in Cameroon: Prevalence, Reasons and Complications. Open Journal of Obstetrics and Gynaecology, 5, 475-480. https://doi.org/10.4236/ojog.2015.59069

[9] Kamga, D.V.T., Nana, P.N., Fouelifack, F.Y. and Fouedjio, J.H. (2017) Contribution of Abortions and Ectopic Pregnancies in the Maternal Mortality of Three University Teaching Hospitals in Yaounde. The Pan African Medical Journal, 27, 248.

[10] Singh S, Remez L, Sedgh G, Kwok L, and Onda T. (2018) Abortion Worldwide 2017: Uneven Progress and Unequal Access. Guttmacher Institute, New York.

[11] United Nations (2015) New York: From MDGs to SDGs: General Introduction. http://www.who.int/gho/publications/mdgs-sdgs/MDGs-SDGs2015_chapter1.pdf

[12] Tiruneh, G.T., Karim, A.M., Avan, B.I., Zemichael, N.F., Wereta, T.G., Wickrema- 
singhe, D., Keweti, Z.N., Kebede, Z. and Betemariam, W.A. (2018) The Effect of Implementation Strength of Basic Emergency Obstetric and Newborn Care (BEmONC) on Facility Deliveries and the Met Need for BEmONC at the Primary Health Care Level in Ethiopia. BMC Pregnancy and Childbirth, 18, Article No. 123. https://doi.org/10.1186/s12884-018-1751-Z

[13] Post Abortion Care (PAC) Consortium Task Force (2014) Essential Elements of Post Abortion Care: Service Delivery, Barriers and Resources. Post Abortion Care Consortium, New York, 11 p.

[14] Ministry of Public Health (2016) Cameroon Analytic Health Profile. Ministry of Public Health, Yaounde, $143 \mathrm{p}$.

[15] National Institute of Statistics (2011) 4th Demographic and Health Survey (DHS-MICS)-Cameroon. Cameroon Ministry of Economy Planning and Territorial Development, Yaounde, $576 \mathrm{p}$.

[16] Family Planning 2020 Initiative. Cameroon Government Commitment, Yaounde. http://www.familyplanning2020.org/countries

[17] Foumane, P., Chiabi, A., Kamdem, C., Monebenimp, F., Dohbit, J.S. and Mbu, R.E. (2013) Sexual Activity of Adolescent School Girls in an Urban Secondary School in Cameroon. Journal of Reproduction \& Infertility, 14, 85-89.

[18] Nkwabong, E., Bechem, E. and Fomulu, J.N. (2014) Outcome of Clandestine Abortions in Two University Teaching Hospitals in Yaounde, Cameroon. Health Sciences and Disease, 15, 1-4.

[19] Cameroon Ministry of Justice (2016) Cameroon Penal Code. 2016 [Law N ${ }^{0}$ 2016/007, Chapter IV, Sections 337 and 339]; 129-130.

[20] Huber, D., Curtis, C., Irani, L., Pappa, S. and Arrington, L. (2016) Post Abortion Care: 20 Years of Strong Evidence on Emergency Treatment, Family Planning, and Other Programming Component. Global Health: Science and Practice, 4, 481-494. https://doi.org/10.9745/GHSP-D-16-00052

[21] Aantjes, C.J., Gilmoor, A., Syurina, E.V. and Crankshaw, T.L. (2018) The Status of Provision of Post Abortion Care Services for Women and Girls in Eastern and Southern Africa: A Systematic Review. Contraception, 98, 77-88.

https://doi.org/10.1016/j.contraception.2018.03.014

[22] Rabiu, K.A., Omololu, O.M., Ojo, T.O., Adewunmi, A.A. and Alugo, B.G. (2009) Unsafe Abortion in Lagos, Nigeria: A Continuing Tragedy. Nigerian Postgraduate Medical Journal, 16, 251-255.

[23] Gerdts, C., Prata, N. and Gessessew, A. (2012) An Unequal Burden: Risk Factors for Severe Complications Following Unsafe Abortion in Tigray, Ethiopia. International Journal of Gynecology \& Obstetrics, 118, S107-S112.

[24] Udoh, A., Effa, E.E., Oduwole, O., Okusanya, B.O. and Okafo, O. (2016) Antibiotics for Treating Septic Abortion: Systematic Review. Cochrane Database of Systematic Reviews, No. 7, Article No. CD011528. https://doi.org/10.1002/14651858.CD011528.pub2

[25] Dao, B., Blum, J., Thieba, B., Raghavan, S., Ouedraego, M., Lankoande, J. and Winikoff, B. (2007) Is Misoprostol a Safe, Effective and Acceptable Alternative to Manual Vacuum Aspiration for Post Abortion Care? Results from a Randomized Trial in Burkina Faso, West Africa. BJOG, 114, 1368-1375. https://doi.org/10.1111/j.1471-0528.2007.01468.x

[26] Makenzius, M., Oguttu, M., Klingberg-Allvin, M., Gemzell-Daniellson, K., Odero, T.M.A. and Faxelid, E. (2017) Post-Abortion Care with Misoprostol-Equally Effective, Safe and Accepted When Administered by Midwives Compared to Physicians: 
A Randomised Controlled Equivalence Trial in a Low-Resource Setting in Kenya. BMJ Open, 7, e016157. https://doi.org/10.1136/bmjopen-2017-016157

[27] Barnard, S., Kim, C., Park, M.H. and Ngo, T.D. (2015) Doctors or Mid-Level Providers for Abortion. Cochrane Database of Systematic Reviews, No. 7, Article No. CD011242. https://doi.org/10.1002/14651858.CD011242.pub2

[28] Benson, J., Andersen, K., Brahmi, D., Healy, J., Mark, A., Ajode, A. and Griffin, R. (2018) What Contraception Do Women Use after Abortion? An Analysis of 319,385 Cases from Eight Countries. Global Public Health, 13, 35-50. https://doi.org/10.1080/17441692.2016.1174280

[29] Solo, J., Billings, D.L., Aloo-Obunga, C., Ominde, A. and Makumi, M. (2003) Creating Linkages Between Incomplete Abortion Treatment and Family Planning Services in Kenya. Studies in Family Planning, 30, 17-27.

[30] Benson, J., Andersen, K., Healy, J. and Brahmia, D. (2017) What Factors Contribute to Post Abortion Contraceptive Uptake by Young Women? A Program Evaluation in 10 Countries in Asia and Sub-Saharan Africa. Global Health: Science and Practice, 5, 644-657. https://doi.org/10.9745/GHSP-D-17-00085

[31] Esber, A., Foraker, R.E., Hemed, M. and Norris, A. (2014) Partner Approval and Intention to Use Contraception among Zanzibari Women Presenting for Post-Abortion Care. Contraception, 90, 23-28. https://doi.org/10.1016/j.contraception.2014.03.006

[32] Hagos, G., Tura, G., Kahsay, G., Haile, K., Grum, T. and Araya, T. (2018) Family Planning Utilization and Factors Associated among Women Receiving Abortion Services in Health Facilities of Central Zone Towns of Tigray, Northern Ethiopia: A Cross Sectional Study. BMC Women's Health, 18, Article No. 83.

[33] Thiam, F.T., Suh, S. and Moreira, P. (2006) Scaling Up Post Abortion Care Services: Results from Senegal. MSH Occasional Papers, 5, 27 p.

[34] Chukwumalu, K. and Baunach, S. (2017) Uptake of Postabortion Care Services and Acceptance of Postabortion Contraception in Puntland, Somalia. Reproductive Health Matters, 25, 48-57. https://doi.org/10.1080/09688080.2017.1402670

[35] Singh, S. (2006) Hospital Admissions Resulting from Unsafe Abortion: Estimates from 13 Developing Countries. The Lancet, 368, 1887-1892. https://doi.org/10.1016/S0140-6736(06)69778-X

[36] Mugore, S., Kassouta, N.T.K., Sebikali, B., Lundstrom, L. and Saad, A. (2016) Improving the Quality of Post Abortion Care Services in Togo Increased Uptake of Contraception. Global Health: Science and Practice, 4, 495-505. https://doi.org/10.9745/GHSP-D-16-00212

[37] Basinga, P., Moore, A.M., Singh, S.D., Carlin, E.E., Birungi, F. and Ngabo, F. (2012) Abortion Incidence and Post Abortion Care in Rwanda. Studies in Family Planning, 43, 11-20. https://doi.org/10.1111/j.1728-4465.2012.00298.x

[38] Prata, N., Bell, S., Gerdts, C., Holston, M. and Melkamu, Y. (2011) Factors Associated with Choice of Post-Abortion Contraception in Addis Ababa, Ethiopia: Original Research Article. African Journal of Reproductive Health, 15, 51-57.

[39] Rominskia, S.D., Morheb, E.S.K. and Loric, J. (2015) Post-Abortion Contraception Choices of Women in Ghana: A One-Year Review. Global Public Health, 10, 345-353. https://doi.org/10.1080/17441692.2014.992799

[40] Berer, M. (2009) Provision of Abortion by Mid-Level Providers: International Policy, Practice and Perspectives. The Bulletin of the World Health Organization, 87, 58-63. https://doi.org/10.2471/BLT.07.050138

[41] Tripney, J., Kwan, I. and Bird, K.S. (2013) Post Abortion Family Planning Counsel- 
ing and Services for Women in Low-Income Countries: A Systematic Review. Contracept, 87, 17-25. https://doi.org/10.1016/j.contraception.2012.07.014

[42] Kalu, C.A., Umeora, O.U. and Sunday-Adeoye, I. (2012) Experiences with Provision of Post-Abortion Care in a University Teaching Hospital in South-East Nigeria: A Five-Year Review. African Journal of Reproductive Health, 16, 105-112.

[43] Evens, E., Otieno-Masaba, R., Eichleay, M., Mccarraher, D., Hainsworth, G., Lane, C., Makumi, M. and Onduso, P. (2014) Post-Abortion Care Services for Youth and Adult Clients in Kenya: A Comparison of Services, Client Satisfaction and Provider Attitudes. Journal of Biosocial Science, 46, 1-15. https://doi.org/10.1017/S0021932013000230

[44] Okusanya, B.O., Oduwole, O. and Effa, E.E. (2014) Immediate Post Abortal Insertion of Intrauterine Devices. Cochrane Database of Systematic Reviews, No. 7, Article No. CD001777. https://doi.org/10.1002/14651858.CD001777.pub4

[45] Mutua, M.M., Achia, T.N.O., Maina, B.W. and Izugbara, C.O. (2017) A Cross Sectional Analysis of Kenyan Post Abortion Care Services Using a National Representative Sample. International Journal of Gynecology \& Obstetrics, 138, 276-282. https://doi.org/10.1002/ijgo.12239

[46] World Health Organization (2015) Health Worker Roles in Providing Safe Abortion Care and Post-Abortion Contraception. WHO, Geneva, 92 p.

[47] Paul, M., Gemzell-Danielsson, K., Kiggundu, C., Namugenyi, R. and Klingberg-Alvin, M. (2014) Barriers and Facilitators in the Provision of Post-Abortion Care at District Level in Central Uganda-A Qualitative Study Focusing on Task Sharing Between Physicians and Midwives. BMC Health Service Research, 14, Article No. 28. https://doi.org/10.1186/1472-6963-14-28

[48] Kim, C., Barnard, S., Neilson, J.P., Hickey, M., Vazquez, J.C. and Dou, L. (2017) Medical Treatments for Incomplete Miscarriage. Cochrane Database of Systematic Reviews, No. 1, Article No. CD007223. https://doi.org/10.1002/14651858.CD007223.pub4

[49] Tumasang, F., Leke, R.J.I. and Aguh, V. (2014) Expanding the Use of Manual Vacuum Aspiration for Incomplete Abortion in Selected Health Institutions in Yaounde, Cameroon. International Journal of Gynecology \& Obstetrics, 126, S28-S30. https://doi.org/10.1016/j.ijgo.2014.03.014

[50] Maxwell, L., Voetagbe, G., Paul, M. and Mark, A. (2015) Does the Type of Abortion Provider Influence Contraception Uptake after Abortion? An Analysis of Longitudinal Data from 64 Health Facilities in Ghana. BMC Public Health, 15, 586-594. https://doi.org/10.1186/s12889-015-1875-2

[51] Adinma, J.I., Ikeako, L., Adinma, E.D., Ezeama, C.O. and Ugboaja, J.O. (2010) Awareness and Practice of Post Abortion Care Services among Health Care Professionals in Southeastern Nigeria. The Southeast Asian Journal of Tropical Medicine and Public Health, 41, 696-704.

[52] Bain, L.E. and Kongnyuy, E.J. (2018) Eliminating the High Abortion Related Complications and Deaths in Cameroon: The Restrictive Legal Atmosphere on Abortions Is No Acceptable Excuse. BMC Women's Health, 18, Article No. 71. https://doi.org/10.1186/s12905-018-0564-6 